\title{
Rates of Epiphytic Growth of Erwinia amylovora on Flowers Common in the Landscape
}

\author{
K. B. Johnson, T. L. Sawyer, and T. N. Temple, Department of Botany and Plant Pathology, Oregon State Univer- \\ sity, Corvallis 97331-2902
}

\begin{abstract}
Johnson, K. B., Sawyer, T. L., and Temple, T. N. 2006. Rates of epiphytic growth of Erwinia amylovora on flowers common in the landscape. Plant Dis. 90:1331-1336.

We evaluated epiphytic growth of the fire blight bacterium, Erwinia amylovora, on flowers of plant species common to landscapes where pears and apples are grown. The plants were from genera regarded as important nectar and pollen sources for pollinating insects: Acer, Amelanchier, Brassica, Cytisus, Populus, Prunus, Rubus, Salix, Taraxacum, Trifolium, and Symphoricarpos. Floral bouquets were inoculated with E. amylovora and incubated in growth chambers at $15^{\circ} \mathrm{C}$ for $96 \mathrm{~h}$. Regardless of their susceptibility to fire blight, all species from the rose family except Prunus domestica (European plum) supported epiphytic populations of E. amylovora that exceeded $1 \times 10^{6} \mathrm{CFU} /$ flower with relative growth rates for the populations that averaged $7 \%$ per hour. Nonrosaceous plants were generally poor supporters of epiphytic growth of the fire blight pathogen with relative growth rates averaging $<4 \%$ per hour. In two seasons of field inoculations, the rosaceous non-disease-host plants, Prunus avium (sweet cherry) and Rubus armeniacus (Himalayan blackberry), yielded mean population sizes of E. amylovora that exceeded $1 \times$ $10^{6} \mathrm{CFU} /$ flower; in contrast, at 8 days after inoculation, mean population sizes of the pathogen were in the range of $5 \times 10^{3}$ to $5 \times 10^{4} \mathrm{CFU} /$ flower on Cytisus scoparius (Scotch broom) and $<1$ $\times 10^{2} \mathrm{CFU}$ on Acer macrophylum (big leaf maple). Because vectors of E. amylovora, principally bees, visit many kinds of flowers in landscape areas between pear and apple orchards, flowers of rosaceous, non-disease-host species could serve as potential sites of inoculum increase during their periods of bloom.
\end{abstract}

Additional keywords: Malus pumila, Pyrus communis

Fire blight, caused by the bacterium Erwinia amylovora, is a serious disease of pear, apple, and other plants of the rose family (21). Commonly, this disease is initiated when $E$. amylovora enters the host via natural openings in the floral nectary (23). Prior to infection, E. amylovora grows as an epiphyte on the floral stigma $(4,16,17,22)$, where it can greatly increase its population size. The large population size enhances the likelihood of floral infection and of further movement to noncolonized flowers $(4,5)$.

Knowledge of the epiphytic nature of the fire blight pathogen on host stigmas has been instrumental in the development of models for timing chemical and biological sprays that suppress floral infection $(13,14,18)$. Environmental conditions favorable for floral infection are relatively easy to quantify and index $(13,14,18)$, but index thresholds that trigger a management action generally assume that pathogen inoculum is present. Frequently this as-

Corresponding author: K. B. Johnson

E-mail: johhnsonk@science.oregonstate.edu

Accepted for publication 22 May 2006.

DOI: 10.1094/PD-90-1331

(C) 2006 The American Phytopathological Society sumption is invalid, which contributes to inaccurate forecasts of infection events. Direct monitoring of orchards for epiphytic E. amylovora is not practiced widely owing to the cost of sampling and to the rapidity at which epiphytic populations can change (8). Adjustment of thresholds for expected, non-weatherrelated variation in disease risk, however, has proven useful. Example adjustments are for cultivar susceptibility and the disease history of an orchard (13).

With regard to disease expectations, a consistent observation that we (and others $[1,2])$ have made in the northwestern United States concerns the association of fire blight with later as opposed to earlier timings of bloom. Factors affecting bloom timing include crop species and cultivar, orchard elevation, and importantly, the presence or absence of secondary types of bloom (2). A higher incidence of fire blight with later bloom timings is explained partially by a greater frequency of warm temperatures as summer approaches; however, this reason for a seasonal effect on fire blight risk is accounted for by current disease warning models. We hypothesized that increasing disease risk is also related to greater abundance of pathogen inoculum, but knowledge of the factors that contribute to inoculum abundance are not well documented.
E. amylovora overwinters in host branches diseased in the previous season, but old cankers are often very difficult to locate and observe once winter pruning and sanitation activities have occurred. Nonetheless, on a spatial scale that is poorly understood, the annual disease cycle is initiated when a small number of cells of the pathogen are moved from a canker to the surfaces of a few flowers. Once introduced to flowers, the pathogen can undergo many cycles of reproduction and dissemination without a requirement to reenter a host. Because many bacterial epiphytes of flowers are not pathogens (16), we became interested in understanding the degree to which E. amylovora could be a floral epiphyte of plants that do not normally host the disease. In fruit production areas, plant species with some stage of bloom can be present for periods approaching 10 weeks, and bees and other pollinating insects visit many kinds of flowers in the vicinity of pear and apple orchards. Thus, as the spring season progresses, the diversity and number of floral habitats where an epiphyte could reside expand, which in the case of E. amylovora could contribute to a seasonal bias in timing of fire blight infections. The objective of this study was to evaluate the epiphytic capability of E. amylovora on flowers of plant species common to landscapes where pears and apples are grown.

\section{MATERIALS AND METHODS}

Bacterial strains. Spontaneous selections derived from E. amylovora strain 153 (Ea153) were used in all experiments. Ea153 was first isolated in 1989 from a diseased apple branch from MiltonFreewater, OR. Growth chamber studies in 2002 and 2003 were conducted with strain Ea153N, which is resistant to nalidixic acid. Growth chamber studies in 2004 and field studies in 2004 and 2005 were conducted with strain Ea153S, which is resistant to streptomycin sulfate. Both Ea153N and Ea153S have shown growth characteristics and pathogenicity similar to the parental strain (K. B. Johnson, unpublished). Bacteria were prepared for experiments by culturing lawns of each strain on nutrient agar (Difco Laboratories, Detroit, MI) amended with $1 \%$ (wt/vol) glycerol. After 5 days incubation at 20 to $24^{\circ} \mathrm{C}$, the bacteria were harvested with a spatula and lyophilized (5,15). Dried cultures were ground with a mortar and pestle and 
screened to a final mesh size of $0.3 \mathrm{~mm}^{2}$. Preparations of lyophilized bacteria were stored at $-50^{\circ} \mathrm{C}$; titers of these preparations averaged 1 to $2 \times 10^{11} \mathrm{CFU} / \mathrm{g}$ and were reevaluated periodically by serial dilution plating.

Selection of plant species. The reference Plants for Beekeeping in Canada and the Northern United States (11), was used as a guide to the selection of flowers that were investigated in growth chamber and field experiments. This book lists important nectar and pollen sources for bees in the major ecoregions across the North American continent. Plant genera listed for ecoregions of northwestern Canada and the United States included Acer, Amelanchier, Brassica, Salix, Cytisus, Malus, Populus, Prunus, Rubus, Salix, Symphiocarpos, Taraxacum, and Trifolium. Floral bouquets of species from these genera were collected from managed and natural landscapes near Corvallis, OR (Table 1). Flowers from four additional genera that grow commonly in western Oregon also were collected: Crataegus, Rhododendron, Rosa, and Vaccinium.

Growth chamber experiments. Flowers of selected species were sampled as each plant bloomed during the spring seasons of 2002 to 2004. At the time of collection, blossom-bearing branches were placed in plastic pails with the proximal end of the branch submerged in water. Newly opened blossoms were harvested with the pedicel (or in some cases, the peduncle) intact and placed onto 80 -well, polypropylene microcentrifuge tube racks (Fisher Scientific, Pittsburgh, PA) with the proximal end of the pedicel submerged into a well that contained $2 \mathrm{ml}$ of $10 \%$ (wt/vol) sucrose (6).
Inoculation of flowers followed a standard protocol, although variation in size and morphology among the species resulted in differences in the sample unit used to measure the potential for epiphytic growth of E. amylovora (Table 1). Suspensions of Ea153N or Ea153S were prepared by resuspending a freeze-dried preparation in distilled water to achieve a concentration of $1 \times 10^{7} \mathrm{CFU} / \mathrm{ml}$. These suspensions were misted onto blossoms to near runoff using a reagent atomizer (Kontes Glass Co., Vineland, NJ). Racks holding inoculated flowers were transferred to 6-liter plastic, lidded boxes (Rubbermaid, Wooster, $\mathrm{OH}$ ), the floors of which were flooded with $500 \mathrm{ml}$ of a $40 \%$ glycerol solution $(\mathrm{v} / \mathrm{v})$ to maintain a relative humidly of 93 to $94 \%$ (6). Boxes containing the racks of blossoms were then incubated for $96 \mathrm{~h}$ in nonlighted growth chambers (VWR Scientific Model 2105, Sheldon Mfg., Inc., Cornelius, OR) set to $15^{\circ} \mathrm{C}$. Two or three replicates of each plant species were inoculated each season; 8 (2002 and 2003) or 12 (2004) flowers per replicate were washed at each sampling time. In 2004, half of the blossoms were inoculated with Ea153S suspended in water. For the other half, the pathogen inoculum was resuspended in a solution containing $100 \mu \mathrm{g} / \mathrm{ml}$ streptomycin sulfate. The purpose of this amendment was to suppress potential competition from indigenous bacterial epiphytes that were residing on the fieldgrown flowers $(7,16)$.

The population size of E. amylovora on the sampled floral organs was determined by dilution plating at sampling times of 0 and $96 \mathrm{~h}$ after inoculation. Floral pistils from individual flowers (Table 1) were removed and placed into $1 \mathrm{ml}$ of sterile 10
$\mathrm{mM}$ phosphate buffer, $\mathrm{pH}$ 7.0. After sonication $(2 \mathrm{~min})$ to dislodge the bacteria from surfaces, the wash buffer and two serial 100-fold dilutions were spread onto CCT medium (defined by Ishimaru and Klos, 3) amended with nalidixic acid (50 $\mu \mathrm{g} / \mathrm{ml}$ ) for selective recovery of Ea153N or streptomycin sulfate $(100 \mu \mathrm{g} / \mathrm{ml})$ for recovery of Ea153S. Colonies of E. amylovora were counted after 3 or 4 days incubation at 20 to $24^{\circ} \mathrm{C}$. The detection limit of the dilution plating procedure was $1 \times 10^{2}$ CFU/flower.

In 2004 experiments, for each replicate, the wash from three blossoms that received Ea153S in water also was dilution plated onto Pseudomonas agar F (PAF, Difco Laboratories, Detroit, MI). This medium was used to measure the total population size of culturable bacteria on the floral surfaces (Ea153N and indigenous bacterial epiphytes).

Field inoculations. Based on results of the growth chamber experiments, sweet cherry, big leaf maple, Scotch broom, and Himalayan blackberry were selected to evaluate their ability to support epiphytic growth of E. amylovora under field conditions at sites near Corvallis, OR. In 2004 and 2005, as each species bloomed, a total of 9 stems (on one to several plants) were flagged; newly open flowers on these stems were marked by securing a small piece of colored tape around the pedicel. Suspensions of Ea153S $\left(1 \times 10^{7} \mathrm{CFU} / \mathrm{ml}\right)$ were prepared as described above and misted onto blossoms to near runoff with a handheld, adjustable trigger sprayer (0.5liter capacity). Three stems were inoculated with Ea153S resuspended in distilled water, and three received the same inoculum resuspended in a solution of strepto-

Table 1. Plants species selected to evaluate their potential to support epiphytic growth of Erwinia amylovora on stigmatic surfaces

\begin{tabular}{|c|c|c|c|c|c|}
\hline Plant family & Botanical name $^{a}$ & Common name ${ }^{a}$ & $\begin{array}{l}\text { Inflorescence } \\
\text { type }\end{array}$ & $\begin{array}{l}\text { Flowers per } \\
\text { inflorescence }\end{array}$ & $\begin{array}{l}\text { Part(s) of } \\
\text { individual flower } \\
\text { washed }\end{array}$ \\
\hline Aceraceae & Acer macrophyllum Pursh. & Big leaf maple & Raceme & $\sim 65$ & Pistil \\
\hline Caprifoliaceae & Symphoricarpos albus (L.) Blake & Common snowberry & Raceme & $8-11$ & Stigma, style \\
\hline Compositae & $\begin{array}{l}\text { Taraxacum officinale G. H. Webber } \\
\text { ex Wiggers }\end{array}$ & Common dandelion & Capitulum & $\sim 100$ & Whole flower \\
\hline Cruciferae & Brassica rapa $\mathrm{L}$. & Field mustard & Raceme & $4-6$ & Stigma, style \\
\hline Ericaceae & Vaccinium corymbosum L. & Highbush blueberry & Raceme & $7-10$ & Pistil, hypanthium \\
\hline Ericaceae & $\begin{array}{l}\text { Rhododendron macrophyllum D. Don } \\
\text { ex G. Don }\end{array}$ & Pacific rhododendron & Corymb & $1-14$ & Stigma, style \\
\hline Fabaceae & Cytisus scoparius (L.) Link & Scotch broom & Solitary & 1 & Pistil \\
\hline Leguminosae & Trifolium repens $\mathrm{L}$. & White clover & Raceme & $\sim 50$ & Whole flower \\
\hline Rosaceae & $\begin{array}{l}\text { Amelanchier alnifolia (Nutt.) Nutt. } \\
\text { ex M. Roemer }\end{array}$ & Saskatoon serviceberry & Raceme & $10-15$ & Pistils, hypanthium \\
\hline Rosaceae & Crataegus douglasii Lindl. & Black hawthorn & Corymb & 12 & Pistil, hypanthium \\
\hline Rosaceae & Malus pumila P. Mill. & Apple & Cyme & 5 & Pistils \\
\hline Rosaceae & Prunus avium (L.) L. & Sweet cherry & Corymb & $5-7$ & Pistil \\
\hline Rosaceae & Prunus persica (L.) Batsch & Peach & Solitary & 1 & Pistil \\
\hline Rosaceae & Prunus domestica L. & European plum & Fasicle & $2-5$ & Pistil, hypanthium \\
\hline Rosaceae & Rosa nutkana K. Presl & Nootka rose & Solitary & 1 & Stigmas, styles \\
\hline Rosaceae & Rubus armeniacus Focke & Himalayan blackberry & Cyme & $3-6$ & Pistils \\
\hline Salicaceae & Salix hookeriana Barratt ex Hook. & Dune willow & Catkin & $\sim 100$ & Pistil \\
\hline Salicaceae & $\begin{array}{l}\text { Salix } \times \text { sepulcralis Simonkai } \\
\quad[\text { alba } \times \text { ?pendulina }]\end{array}$ & Weeping willow & Catkin & $\sim 80$ & Pistil \\
\hline Salicaceae & Populus deltoides Bartr. ex Marsh. & Eastern cottonwood & Catkin & $\sim 30$ & Stigmas, styles \\
\hline
\end{tabular}

${ }^{a}$ USDA PLANTS database (20). 
mycin sulfate $(100 \mu \mathrm{g} / \mathrm{ml})$. The last three stems were sprayed with distilled water only. Dates of field inoculations in 2004 were 29 March for sweet cherry and big leaf maple, 10 May for Scotch broom, and 25 May for Himalayan blackberry. In 2005, the inoculation dates were 31 March, 11 and 28 April, and 14 June for cherry, maple, broom, and blackberry, respectively. For an inoculation event, the relative favorability of the environment for epiphytic growth of E. amylovora was summarized by estimating the total degreehours base $10^{\circ} \mathrm{C}\left({ }^{\circ} \mathrm{h}\right)$ over the 8 -day period. Degree-hours were estimated from daily minimum and maximum temperatures following a method we developed previously (6).

Flowers were sampled from the field sites at 0,4 , and 8 days after inoculation to measure the population size of Ea153S and associated indigenous epiphytes on the surfaces of pistils. Ten flowers per stem replicate were sampled at each sampling time. The flowers were processed and washed as described above and then dilution plated onto PAF and onto CCT amended with streptomycin sulfate $(100 \mu \mathrm{g} / \mathrm{ml})$.

Weather data were obtained from a station located at an experimental field site near Corvallis, OR. The station is part of the AgriMet Pacific Northwest Cooperative Agricultural Weather Network (U.S. Bureau of Reclamation, Boise, ID); the data are available at their website.

Data summary and analysis. Mean population sizes of strains of Ea153 were summarized for each sample date. Prior to averaging, estimates of bacterial population size on individual blossoms were transformed to $\log _{10}(6)$. Blossoms sampled from the field sites onto which $E$. amylovora was inoculated but could not be detected were assigned a value of one-half of the detection limit (i.e., $50 \mathrm{CFU} /$ flower).

For comparisons among plant species, a relative growth rate for E. amylovora (proportional increase in population size per hour, $r$ ) was computed for each replication of the growth chamber experiments:

$$
r=1 / 96 \cdot\left[\ln \left(y_{96}\right)-\ln \left(y_{\text {zero }}\right)\right]
$$

where $y_{\text {zero }}$ and $y_{96}$ are bacterial population sizes near the time of inoculation and after $96 \mathrm{~h}$, respectively (6). Replicate values of the relative growth rate were subjected to analysis of variance (ANOVA) with plant species as the main effect. Ea153N replicates from 2002 (two) and 2003 (three) were combined for this analysis. For the 2004 experiment, a two-way ANOVA was performed initially to test the effects of plant species and the presence of streptomycin on the relative growth rate of Ea153S; when no effect of streptomycin was observed, a second ANOVA was conducted with plant species as the only main effect. Means for relative growth rate were compared among species with Fisher's protected least significant difference at $P=$ 0.01 .

For the field studies, environmental conditions following the inoculations were summarized for each plant species by tabu- lating the frequency of recovery and population size of indigenous bacteria on the water-treated flowers as well as rainfall amount and degree-hours accumulated during the 8-day postinoculation periods. Within each plant species, the null hypothesis that treatment with streptomycin had no effect on frequency of recovery or population size of Ea153S was evaluated by ANOVA. Separate ANOVA analyses were conducted to determine if the main effect of plant species affected frequency of recovery or population size of the pathogen.

\section{RESULTS}

Growth chamber experiments. Inflorescence type and flower size varied among the plant species (Table 1), and this variation resulted in initial population sizes of E. amylovora on each species that ranged from $5 \times 10^{2}$ to $5 \times 10^{4}$ CFU/flower. After $96 \mathrm{~h}$ of incubation, all plant species hosted higher population sizes of E. amylovora compared with the populations measured immediately after inoculation (Table 2). Among plant species, final mean population sizes of $E$. amylovora varied from $8 \times 10^{3}$ (on weeping willow) to $8 \times 10^{7} \mathrm{CFU} /$ flower (on Himalayan blackberry in 2002 and 2003 and Nootka rose in 2004). Plants of the rose family - apple, Himalayan blackberry, Saskatoon serviceberry, sweet cherry, black hawthorn, peach, and Nootka roseeach supported mean populations of the fire blight pathogen that exceeded $1 \times 10^{6}$

Table 2. Initial population size $\left(\log _{10}[\mathrm{CFU} / \mathrm{flower}]\right)^{\mathrm{a}}$, final population size after incubation at $14^{\circ} \mathrm{C}$ for $96 \mathrm{~h}$, and estimated relative growth rate of Erwinia amylovora strain 153N (2002-2003) or strain 153S (2004) on detached flowers of 19 common plant species sampled from areas near Corvallis, OR, during spring seasons of 2002-2004

\begin{tabular}{|c|c|c|c|c|c|c|}
\hline \multirow[b]{2}{*}{ Host } & \multicolumn{3}{|c|}{$2002-2003$} & \multicolumn{3}{|c|}{2004} \\
\hline & $\begin{array}{c}\text { Initial } \\
\text { population size } \\
\left(\log _{10}[\text { CFU/flower }]\right)\end{array}$ & $\begin{array}{c}\text { Final } \\
\text { population size } \\
\left(\log _{10}[\text { CFU/flower }]\right)\end{array}$ & $\begin{array}{c}\text { Growth } \\
\text { rate } \\
(\% / h)\end{array}$ & $\begin{array}{c}\text { Initial } \\
\text { population size } \\
\left(\log _{10}[\text { CFU/flower }]\right)\end{array}$ & $\begin{array}{c}\text { Final } \\
\text { population size } \\
\left(\log _{10}[\text { CFU/flower }]\right)\end{array}$ & $\begin{array}{c}\text { Growth } \\
\text { rate } \\
(\% / h)\end{array}$ \\
\hline Apple & $3.60 \pm 0.05^{\mathrm{b}}$ & $7.59 \pm 0.11$ & $9.6^{c} \pm 0.2$ & $4.30 \pm 0.05$ & $7.42 \pm 0.13$ & $7.5 \pm 0.8$ \\
\hline Saskatoon serviceberry & $3.26 \pm 0.30$ & $7.19 \pm 0.14$ & $9.4 \pm 0.4$ & $4.65 \pm 0.10$ & $7.28 \pm 0.25$ & $6.3 \pm 1.6$ \\
\hline Common snowberry & $2.46 \pm 0.15$ & $6.13 \pm 0.08$ & $8.9 \pm 0.2$ & $3.81 \pm 0.13$ & $4.57 \pm 0.16$ & $4.3 \pm 0.4$ \\
\hline Himalayan blackberry & $4.21 \pm 0.18$ & $7.81 \pm 0.11$ & $8.6 \pm 0.5$ & $4.46 \pm 0.22$ & $7.20 \pm 0.26$ & $6.6 \pm 0.6$ \\
\hline Black hawthorn & $3.24 \pm 0.01$ & $6.63 \pm 0.23$ & $8.1 \pm 0.5$ & $4.17 \pm 0.12$ & $7.14 \pm 0.15$ & $7.1 \pm 1.2$ \\
\hline Sweet cherry & $3.26 \pm 0.11$ & $6.35 \pm 0.05$ & $7.4 \pm 0.3$ & $3.59 \pm 0.06$ & $6.24 \pm 0.09$ & $6.4 \pm 0.8$ \\
\hline Scotch broom & $3.89 \pm 0.05$ & $6.87 \pm 0.15$ & $7.1 \pm 0.4$ & $3.55 \pm 0.07$ & $6.94 \pm 0.25$ & $8.1 \pm 1.5$ \\
\hline Peach & $3.70 \pm 0.06$ & $6.64 \pm 0.21$ & $7.0 \pm 0.6$ & $3.77 \pm 0.05$ & $6.60 \pm 0.20$ & $6.8 \pm 1.2$ \\
\hline Nootka rose & $4.14 \pm 0.03$ & $6.91 \pm 0.17$ & $6.7 \pm 0.4$ & $4.14 \pm 0.04$ & $7.75 \pm 0.04$ & $8.2 \pm 0.5$ \\
\hline European plum & $3.75 \pm 0.11$ & $5.82 \pm 0.17$ & $5.0 \pm 0.4$ & $3.80 \pm 0.02$ & $5.99 \pm 0.10$ & $5.3 \pm 0.3$ \\
\hline Highbush blueberry & $2.76 \pm 0.07$ & $4.72 \pm 0.19$ & $4.7 \pm 0.3$ & $3.81 \pm 0.12$ & $5.59 \pm 0.10$ & $4.2 \pm 0.5$ \\
\hline Dune willow & $3.62 \pm 0.17$ & $5.40 \pm 0.34$ & $4.3 \pm 0.6$ & $3.59 \pm 0.26$ & $4.71 \pm 0.31$ & $2.7 \pm 1.1$ \\
\hline Eastern cottonwood & $3.91 \pm 0.06$ & $5.66 \pm 0.07$ & $4.2 \pm 0.3$ & $3.92 \pm 0.06$ & $6.08 \pm 0.29$ & $5.2 \pm 0.8$ \\
\hline Big leaf maple & $3.74 \pm 0.05$ & $5.45 \pm 0.40$ & $4.1 \pm 0.8$ & $4.43 \pm 0.10$ & $6.22 \pm 0.13$ & $4.3 \pm 0.4$ \\
\hline Field mustard & $2.93 \pm 0.16$ & $4.53 \pm 0.43$ & $3.8 \pm 0.7$ & $3.20 \pm 0.03$ & $4.37 \pm 0.29$ & $2.8 \pm 0.8$ \\
\hline Weeping willow & $2.95 \pm 0.09$ & $3.75 \pm 0.42$ & $1.9 \pm 0.8$ & $3.24 \pm 0.10$ & $3.89 \pm 0.28$ & $1.6 \pm 0.8$ \\
\hline Pacific rhododendron & $4.10 \pm 0.08$ & $4.69 \pm 0.30$ & $1.4 \pm 0.9$ & $4.03 \pm 0.07$ & $5.29 \pm 0.24$ & $3.0 \pm 0.6$ \\
\hline Common dandelion & $3.61 \pm 0.26$ & $4.15 \pm 0.72$ & $1.1 \pm 1.3$ & $3.18 \pm 0.05$ & $5.36 \pm 0.10$ & $5.2 \pm 0.3$ \\
\hline White clover & $4.04 \pm 0.07$ & $4.38 \pm 0.20$ & $0.9 \pm 0.5$ & $3.86 \pm 0.10$ & $5.47 \pm 0.11$ & $3.8 \pm 0.4$ \\
\hline LSD $P=0.01^{\mathrm{d}}$ & & & 2.3 & & & 1.6 \\
\hline
\end{tabular}

${ }^{\text {a }}$ For each season, flowers were misted to near runoff with cells of $E$. amylovora $\left(1 \times 10^{7} \mathrm{CFU} / \mathrm{ml}\right)$ resuspended from the same freeze-dried culture of the pathogen; individual dates of inoculation corresponded to the bloom time of each species.

b Standard error of mean; based on 5 (2002-2003) or 6 (2004) replicates of 6 (2004) or 8 (2002-2003) individual flowers per replication.

${ }^{\mathrm{c}}$ Growth rate calculated as: $r=\left\{1 / 96 \cdot\left[\ln \left(y_{96}\right)-\ln \left(y_{\text {zero }}\right)\right]\right\} \cdot 100$, where $y_{\text {zero }}$ and $y_{96}$ were the replicate means for population size of E. amylovora (CFU/flower) near the time of inoculation and after $96 \mathrm{~h}$, respectively.

d Fisher's protected least significant difference at $P=0.01$. 
CFU/flower during each experiment. For nonrosaceous plants, high mean populations of E. amylovora $\left(>1 \times 10^{6}\right.$ CFU/flower) were recovered from Scotch broom in each season of experimentation, and from flowers of common snowberry, big leaf maple, and eastern cottonwood in one of the inoculation experiments. In 2004, relative to inoculum prepared by resuspending streptomycin-resistant strain

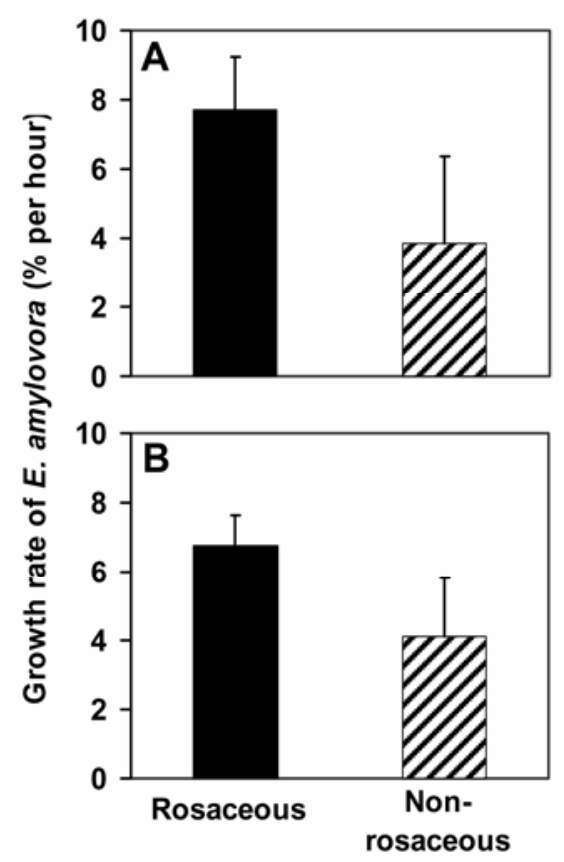

Fig. 1. Estimates of relative growth rates $(\% / \mathrm{h})$ of A, Erwinia amylovora strain 153N (20022003 experiments) and B, E. amylovora strain 153S (2004 experiments) on detached flowers of 8 plant species from the rose family (solid bars) and 11 plant species from other families (hatched bars) (see Table 1). Growth rates were estimated after a 96-h incubation period in growth chambers held at a constant temperature of $14^{\circ} \mathrm{C}$. Vertical line on top of each bar indicates one standard error of the mean.
Ea153S in water, the addition of streptomycin sulfate $(100 \mu \mathrm{g} / \mathrm{ml})$ to inoculum of Ea153S had no effect on the number of colony-forming units of the pathogen recovered at either 0 or 4 days after inoculation. For flowers that received Ea153S in water, faster growth of recovered colonies of the pathogen on the nonselective PAF resulted in colony numbers that averaged $95 \%$ of those obtained on the selective, colony-size-restricting CCT medium. Also on PAF, the incidence of bacteria other than Ea153S was observed only rarely.

As for final population size, the relative growth rate of E. amylovora on flowers varied greatly among the plant species (Table 2), and ranged from $0.9 \% / \mathrm{h}$ (on white clover in 2002 and 2003) to $9.6 \% / \mathrm{h}$ (on apple in 2002 and 2003). As a group, rosaceous plants supported significantly higher $(P<0.01)$ relative growth rates of the fire blight pathogen on flowers (mean $7.3 \% / \mathrm{h}$ ) than did nonrosaceous plants (mean $4.0 \% / \mathrm{h}$ ) (Fig. 1). For nonrosaceous plants, relative growth rates of E. amylovora comparable to the mean growth rate on rosaceous plants were observed only on Scotch broom $(7.1$ and $8.1 \% / \mathrm{h}$ in 2002 and 2003, respectively, and $8.1 \% / \mathrm{h}$ in $2004)$ and snowberry $(8.1 \% / \mathrm{h}$ in 2002 and 2003).

Field inoculations. Field inoculations of Ea153S onto newly open flowers of sweet cherry, big leaf maple, Scotch broom, and Himalayan blackberry were timed to coincide with periods when temperatures were expected to allow for epiphytic growth of bacteria on floral surfaces. For 7 of 8 inoculations, we concluded these timings were successful with total degree-hour accumulations (base $10^{\circ} \mathrm{C}$ ) over the 8-day postinoculation periods that ranged from $193{ }^{\circ} \mathrm{h}$ after inoculation of sweet cherry in 2005 to $1002{ }^{\circ} \mathrm{h}$ after inoculation of Himalayan blackberry in 2005 (Table 3). In contrast, after inocu- lation of big leaf maple in 2005, only $68^{\circ} \mathrm{h}$ were accumulated over the 8-day period. Rain events occurred during each of the postinoculation periods, with larger amounts of rain recorded in 2005 than in 2004; the most rain $(28 \mathrm{~mm})$ occurred after the inoculation of big leaf maple in 2005 .

Averaged over host and sampling time, indigenous bacteria were recovered from $60 \%$ of sampled flowers with mean population sizes (per host per sample date) that ranged from $1.0 \times 10^{2}$ to $1.5 \times 10^{4}$ CFU/flower (Table 3). Compared with flowers inoculated with Ea153S resuspended in water, the addition of streptomycin sulfate to inoculum of the pathogen generally resulted in a 10 to $20 \%$ decrease in both the incidence of recovery and the population size of indigenous bacteria and a corresponding small (5 to 10\%) but generally insignificant $(P \geq 0.05)$ increase in the recovery and population size of Ea153S (data not shown). An exception was Scotch broom in 2005, where at 8 days after inoculation, the addition of streptomycin to the initial inoculum increased the incidence of recovery of Ea153S by 11 -fold (from 8 to $92 \%$ ) and the mean population size of the pathogen by a similar magnitude (from 1.81 to 3.11 $\log _{10}(\mathrm{CFU} /$ flower $)$ ). As a consequence of this result, pathogen incidence and population size data from the treatment of Ea153S resuspended with streptomycin sulfate were used to make comparisons among the inoculated host species.

As in the growth chamber experiments, large populations of Ea153S developed on floral stigmas of the rosaceous plants, sweet cherry and Himalayan blackberry (Fig. 2). For these hosts, initial populations of Ea153S were in the 2.7 to 4.9 $\log _{10}$ (CFU/flower) range with the estimated population size increasing by approximately 100 -fold over the 8 -day period. The incidence of recovery of Ea153S

Table 3. Summary of postinoculation weather conditions and of recovery of indigenous culturable bacteria from individual, water-treated ${ }^{\mathrm{a}}$ flowers of sweet cherry, big leaf maple, Scotch broom, and Himalayan blackberry sampled from field sites near Corvallis, OR, in 2004 and 2005

\begin{tabular}{|c|c|c|c|c|c|c|c|c|}
\hline \multirow[b]{3}{*}{ Host flower } & \multirow[b]{3}{*}{$\begin{array}{c}\text { Degree-hours } \\
\text { during post- } \\
\text { inoculation } \\
\text { period } \\
\left(\text { base } 10^{\circ} \mathrm{C}\right)\end{array}$} & \multirow{3}{*}{$\begin{array}{c}\text { Total } \\
\text { rainfall } \\
\text { during post- } \\
\text { inoculation } \\
\text { period } \\
(\mathrm{mm})\end{array}$} & \multicolumn{6}{|c|}{ Days from water application } \\
\hline & & & \multicolumn{2}{|c|}{0 days } & \multicolumn{2}{|c|}{4 days } & \multicolumn{2}{|c|}{8 days } \\
\hline & & & $\begin{array}{c}\text { Incidence } \\
\text { of recovery } \\
(\%)\end{array}$ & $\begin{array}{c}\text { Population } \\
\text { size }^{\mathrm{c}} \\
\left(\log _{10}[\mathrm{CFU} /\right. \\
\text { flower] }\end{array}$ & $\begin{array}{c}\text { Incidence } \\
\text { of recovery } \\
(\%)\end{array}$ & $\begin{array}{c}\text { Population } \\
\text { size } \\
\left(\log _{10}[\mathrm{CFU} /\right. \\
\text { flower] })\end{array}$ & $\begin{array}{c}\text { Incidence } \\
\text { of recovery } \\
(\%)\end{array}$ & $\begin{array}{c}\text { Population } \\
\text { size } \\
\left(\log _{10}[\mathrm{CFU} /\right. \\
\text { flower }])\end{array}$ \\
\hline \multicolumn{9}{|l|}{2004} \\
\hline Sweet cherry & 366 & 2.5 & 0 & _- & 100 & 2.0 & 100 & 4.1 \\
\hline Big leaf maple & 366 & 2.5 & 83 & 2.3 & 17 & 2.2 & 50 & 2.4 \\
\hline Scotch broom & 595 & 6.4 & 38 & 2.7 & 75 & 2.9 & 100 & 3.0 \\
\hline Himalayan blackberry & 852 & 3.0 & 67 & 2.4 & 67 & 3.2 & 67 & 2.9 \\
\hline \multicolumn{9}{|l|}{2005} \\
\hline Sweet cherry & 193 & 14.0 & 0 & - & 78 & 2.5 & 78 & 3.4 \\
\hline Big leaf maple & 68 & 28.4 & 33 & 2.6 & 78 & 3.3 & 100 & 2.6 \\
\hline Scotch broom & 783 & 11.1 & 11 & 2.6 & 33 & 2.4 & 78 & 2.2 \\
\hline Himalayan blackberry & 1002 & 10.2 & 22 & 2.8 & 100 & 4.5 & 78 & 4.6 \\
\hline
\end{tabular}

${ }^{a}$ Water treatment coincided with inoculations of Erwinia amylovora strain Ea153S onto flowers on other stems of the same plants.

${ }^{b}$ Proportion of flowers from which indigenous culturable bacteria were recovered; Pseudomonas agar F (Difco, Detroit, MI) was used as the recovery medium.

c Average population size of indigenous bacteria on flowers on which bacteria were detected; the detection limit was 100 CFU. 
from cherry and blackberry also remained high through the postinoculation period, with an average of $94 \%$ of inoculated flowers harboring a detectable population of the pathogen after 8 days.

On flowers of big leaf maple, in both seasons, the incidence of recovery and the population size of Ea153S declined over the 8-day postinoculation period. For example, immediately after inoculation, incidence of recovery of Ea153S averaged $95 \%$, but at 8 days after inoculation, Ea153S was recovered from only $15 \%$ of inoculated flowers; moreover, when Ea153S was detected at 4 or 8 days after inoculation, population size was generally just above the detection limit of 100 CFU/flower. In contrast, Scotch broom flowers provided an environment where Ea153S was detected on $86 \%$ of flowers at 8 days after inoculation. Mean population sizes of Ea153S on Scotch broom, however, did not show a net increase from the beginning to the end of the sampling period. Interestingly, however, in both seasons the population size of Ea153S on Scotch broom showed an apparent decrease at the 4-day sample when compared to the 0-day sample but at 8 days after inoculation showed an apparent increase back towards the initial population size estimate. Nonetheless, at 8 days after inoculation, mean population size of Ea153S on flowers of big leaf maple and Scotch broom were significantly $(P<0.01)$ smaller than estimated population sizes on sweet cherry and Himalayan blackberry.

\section{DISCUSSION}

Our rationale for this study was to expand on what is known about the epiphytic biology of E. amylovora to contribute to understanding availability of inoculum within a production area with fruit trees susceptible to this pathogen. Reviews of this topic (e.g., 18) conclude that E. amylovora is a poor epiphyte on host surfaces other than flowers, requiring a resident phase (active or inactive) inside a host to persist for long periods of time. Within the disease cycle, the epiphytic phase on flowers is highly significant because it allows the pathogen, as a prerequisite to infection, to greatly expand its population size from the small number of cells released from cankers produced in the previous season (4). The floral epiphytic phase also facilitates dispersal, which occurs principally via bees and other pollinators. In this regard, several reports in the literature $(1,10)$ implicate common landscape plants that host fire blight (notably hawthorn [Crataegus spp.] and firethorn [Pyracanthus spp.]) as sources of inoculum for infection of pear and apple. Nonetheless, to our knowledge, the idea that flowers of common plants that do not typically host the disease could contribute to persistence of epiphytic populations of this pathogen has never been investigated. Consequently, owing to the significance of insects in the fire blight disease cycle, we limited our scope mostly to common plants that are considered important resources for pollinating insects (11).

This study presented several methodological challenges because the evaluated species bloomed at many different times and produced inflorescences that varied widely in size and morphology. We addressed these challenges by using a freezedried preparation of bacterial inoculum that provided a high degree of consistency among inoculations $(6,15)$ and by using a flower-size independent, relative growth rate calculation to make comparisons among species (6). In addition, because the flowers were sampled from field sites, we were concerned that contamination by indigenous bacterial populations could influence the observed rates of growth of E. amylovora. This concern was addressed with use of a streptomycin-resistant strain Ea153S combined with a streptomycin sulfate amendment to the inoculum suspension. Previously, in a field experiment designed to understand factors influencing dispersal of Pantoea agglomerans among flower populations (7), we found that streptomycin was useful as a tool for suppression of growth of indigenous bacterial populations, and that it had no significant effect on growth or dispersal of the streptomycin-resistant strain of $P$. agglomerans that was the subject of the study. For the experiments reported on in this manuscript, we found that streptomycin did not affect growth of Ea153S on the flowers sampled at a young age and incubated in a growth chamber after inoculation. In at least one field inoculation, however, the niche clearing activity of the streptomycin treatment enhanced both incidence of recovery and population size of Ea153S on flowers that had been open for 4 to 8 days. These observations are consistent with the data of Stockwell et al. (16), who found that indigenous bacteria were recovered rarely from newly open flowers of pear, but that high populations of bacterial epiphytes could develop on the flowers as they aged.

The principal finding of this study is that flowers of plants of the rose family can support large epiphytic populations of E. amylovora even if the species does not typically host fire blight infections. These non-disease-host species include orchard crops such as sweet cherry (Prunus avium), which often grows in close proximity to pear and apple orchards, and also common weeds like Himalayan blackberry (Rubus armeniacus), which grows along edges of orchards and blooms coincident with secondary flowering in pear and apple. Although fire blight of both Prunus and Rubus spp. has been reported (rarely in the case of Prunus spp. [9] and with hostspecific strains in the case of Rubus spp. $[10,12])$, this is the first study to measure epiphytic growth rates of E. amylovora on flowers of these genera in controlled inoculations and to compare these growth rates to those observed on genera that commonly host the disease (e.g., Malus and Crataegus spp.). The results of the growth chamber experiment also indicated that E. amylovora has some potential to increase its population size on flowers of nonrosaceous plants, but growth rates varied by species and were on average smaller than observed on rosaceous plants (Fig. 1). For the field experiments, the observed temporal dynamics of growth and ultimate population sizes of E. amylovora on sweet cherry and Himalayan blackberry flowers were very similar to those we measured previously on pear and apple flowers inoculated at the same location (16). In contrast, the population sizes of E. amylovora on field-inoculated flowers of Scotch broom and big leaf maple were significantly smaller that observed on cherry and blackberry. Also, compared to results obtained with Scotch broom in the growth chamber, the measured population sizes of E. amylovora on field-inoculated flowers of this species were smaller than expected.

Epidemiologically, the primary implication of this study is that E. amylovora may inhabit a larger epiphytic niche than has been recognized previously. In valley production areas of the northwestern United States, fire blight epidemics in pear and apple are sporadic both temporally and

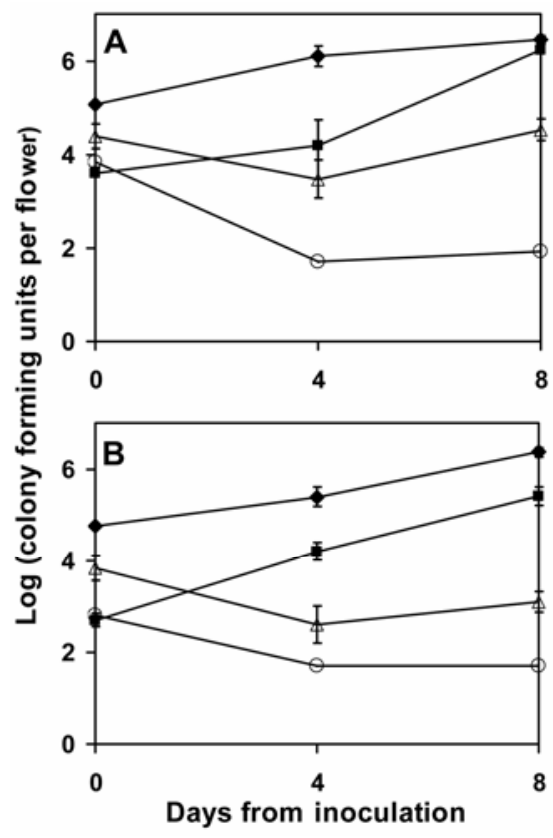

Fig. 2. Population size $\left(\log _{10}[\mathrm{CFU} /\right.$ flower $\left.]\right)$ of Erwinia amylovora strain $153 \mathrm{~S}$ on flowers of sweet cherry (匹), big leaf maple (०), Scotch broom $(\Delta)$, and Himalayan blackberry $(\bullet)$ sampled at $1 \mathrm{~h}, 4$ and 8 days after inoculation at field sites near Corvallis, OR, in A, 2004 and B, 2005. A suspension of Ea153S $\left(1 \times 10^{7}\right.$ $\mathrm{CFU} / \mathrm{ml}$ ) was misted onto to the flowers to near runoff. Vertical line drawn through point indicates \pm one standard error of the mean. 
spatially, being limited by host species and elevation factors that influence when flowers are open and susceptible to infection. Moreover, fire blight frequently fails to develop during the primary bloom, but many pear and some apple cultivars (e.g., cv. Pink Lady) develop the disease during secondary, rattail blooms that occur in late spring and early summer (2). Because vectors of $E$. amylovora, principally bees, visit many kinds of flowers in the landscape, our results suggest that epiphytic inoculum sources of E. amylovora could become more broadly dispersed within a valley or region as a season transitions (e.g., from pear to apple, lower to higher elevation, primary to secondary bloom). Although we highlight Rubus and Prunus as non-disease hosts on which the fire blight pathogen could reproduce inconspicuously, landscape species $(1,10)$ that host fire blight and/or an orchard of a fire blight-resistant apple cultivar (e.g., cv. Red Delicious) also could be involved in this broadening process. The practical consequence of this broadening phenomenon is that action thresholds within temperature-based disease warning models could signal too many treatments in early spring owing to the rarity of inoculum and too few treatments later in the season, as epiphytic sources of the pathogen become more abundant.

One of the first efforts to develop a prediction model for fire blight incorporated time of season as a factor in assessing disease risk (19), but this concept has been neglected in more recent modeling efforts $(13,14)$. The older temperature-line model (19) characterized the minimum mean daily temperatures at which the introduction and buildup of epiphytic inoculum of E. amylovora in healthy pear flowers were observed to occur. The temperature line was seasonally dependent in that a mean daily temperature of $16.7^{\circ} \mathrm{C}$ was required to expect development of detectable epiphytic population in early March, but with the declining slope of the temperature line, a daily mean temperature of only $14.4^{\circ} \mathrm{C}$ was required on May 1. Although Thomson et al. (19) did not comment on the sources of inoculum of E. amylovora that led to epiphytic infestations in healthy pear flowers, the negative slope of the temperature line appears to reflect inoculum of the pathogen becoming more abundant as the spring bloom period advances. The results of our study offer one explanation as to why a seasonal dependency could occur.

\section{ACKNOWLEDGMENTS}

We gratefully acknowledge the support of the Winter Pear Control Committee. We also thank Richard Halse for guidance on botanical terminology and plant species identification.

\section{LITERATURE CITED}

1. Billing, E. 1981. Hawthorn as a source of the fire blight bacterium for pear, apple and ornamental hosts. Pages 121-130 in: Pest, Pathogens and Vegetation, The Role of Weeds and Wild Plants in the Ecology of Crop Pests and Diseases. Pitman, Boston.

2. Covey, R. P., and Fischer, W. R. 1988. The significance of the secondary bloom to fire blight development on Bartlett pears in eastern Washington. Plant Dis. 72:911.

3. Ishimaru, C. A., and Klos, E. J. 1984. New medium for detecting Erwinia amylovora and its use in epidemiological studies. Phytopathology 74:1342-1345.

4. Johnson, K. B., and Stockwell, V. O. 1998. Management of fire blight: A case study in microbial ecology. Annu. Rev. Phytopathol. 36:227-248.

5. Johnson, K. B., Stockwell, V. O., Burgett, D. M., Sugar, D., and Loper, J. E. 1993. Dispersal of Erwinia amylovora and Pseudomonas fluorescens by honey bees to apple and pear blossoms. Phytopathology 83:478-484.

6. Johnson, K. B., Stockwell, V. O., and Sawyer, T. L. 2004. Adaptation of fire blight forecasting to optimize the use of biological controls. Plant Dis. 88:41-48.

7. Johnson, K. B., Stockwell, V. O., and Sugar, D. 2000. Assessment of environmental factors influencing growth and spread of Pantoea agglomerans on and among blossoms of apple and pear. Phytopathology 90:1285-1294.

8. Kritzman, G., Shwartz, H., Marcus, R., Manulis, S., Klietman, F., Oppenheim, D., Zilberstaine, M., and Shtienberg, D. 2003. Testing a rapid diagnostic medium for $\mathrm{Er}$ winia amylovora and development of a procedure for sampling blossoms in pear or- chards. Phytopathology 93:931-940.

9. Mohan, S. K., and Bijman, V. P. 1999. Susceptibility of Prunus species to Erwinia amylovora. Acta Hortic. 489:145-147.

10. Momol, M. T., and Aldwinckle, H. S. 2000. Genetic diversity and host range of Erwinia amylovora. Pages 55-72 in: Fire Blight, The Disease and its Causative Agent, Erwinia amylovora. J. L. Vanneste, ed. CABI Publishing, New York.

11. Ramsay, J. 1987. Plants for Beekeeping in Canada and the Northern United States. Int Bee Res. Assoc., London. pp. 139-143.

12. Ries, S. M., and Otterbacker, A. G. 1977. The occurrence of fire blight on thornless blackberry in Illinois. Plant Dis. Rep. 61:232-235.

13. Smith, T. J. 1996. A risk assessment model for fire blight of apple and pear. Acta Hortic. 411:97-104.

14. Steiner P. W. 1990. Predicting apple blossom infections by Erwinia amylovora using the MARYBLYT model. Acta Hortic. 273:139-148.

15. Stockwell, V. O., Johnson, K. B., and Loper, J. E. 1998. Establishment of bacterial antagonists of Erwinia amylovora on pear and apple blossoms as influenced by inoculum preparation. Phytopathology 88:506-513.

16. Stockwell, V. O., McLaughlin, R. J., Henkels, M. D., Loper, J. E., Sugar, D., and Roberts, R. G. 1999. Epiphytic colonization of pear stigmas and hypanthia by bacteria during primary bloom. Phytopathology 89:1162-1168.

17. Thomson, S. V. 1986. The role of the stigma in fire blight infections. Phytopathology 76:476482.

18. Thomson, S. V. 2000. Epidemiology of fire blight. Pages 9-31 in: Fire Blight, The Disease and its Causative Agent, Erwinia amylovora. J. L. Vanneste, ed. CABI Publishing, New York.

19. Thomson, S. V., Schroth, M. N., Moller, W. J., and Reil, W. O. 1982. A forecasting model for fire blight of pear. Plant Dis. 66:576-579.

20. USDA, NRCS. 2006. The PLANTS Database, 6 March 2006. Data compiled from various sources by M. W. Skinner. Online, National Plant Data Center, Baton Rouge, LA.

21. Van der Zwet, T., and Kiel, H. L. 1992. Fire Blight-A bacterial disease of rosaceous plants. Agric. Handb. 510, USDA Science and Education Administration, Washington D.C.

22. Wilson, M., Sigee, D. C., and Epton, H. A. S 1989. Erwinia amylovora infection of hawthorn blossoms: II. The stigma. J. Phytopathol. 127:15-28.

23. Wilson, M., Sigee, D. C., and Epton, H. A. S. 1990. Erwinia amylovora infection of hawthorn blossom: III. The Nectary. J. Phytopathol. 128:62-74. 